\title{
Risk of second primary cancers after Hodgkin's disease by type of treatment: analysis of 2846 patients in the British National Lymphoma Investigation
}

\author{
A J Swerdlow, A J Douglas, G Vaughan Hudson, B Vaughan Hudson, M H Bennett, K A MacLennan
}

Epidemiological Monitoring Unit, Department of Epidemiology and Population Sciences, London School of Hygiene and Tropical Medicine, London WC1E 7HT

A J Swerdlow, head

A J Douglas, research fellow

British National Lymphoma Investigation, Department of Oncology, University College and Middlesex School of Medicine

G Vaughan Hudson, director B Vaughan Hudson, research fellow

Department of Histopathology, Mount Vernon Hospital, Middlesex

M H Bennett, consultant pathologist

\section{Department of} Histopathology, Royal Marsden Hospital, London K A MacLennan, consultant histopathologist

Correspondence to: Dr Swerdlow.

$B M \mathcal{F}$ 1992;304:1137-43
Abstract

Objective-To analyse the risk of second primary cancers during long term follow up of patients with Hodgkin's disease.

Design-Cohort study.

Setting-The British National Lymphoma Investigation (a collaborative group of over 60 participating centres in Britain treating lymphomas).

Patients -2846 patients first treated for Hodgkin's disease during $1970-87$, for whom follow up was complete in $\mathbf{9 9 . 8 \%}$.

Main outcome measures-Second primary cancers; uniform pathology reviews confirmed the diagnosis of Hodgkin's disease and of second primary non-Hodgkin's lymphomas.

Results-113 second primary cancers occurred. Relative risk of cancer other than Hodgkin's disease was 2.7 (95\% confidence interval 2.3 to 3.3$)$ compared with the general population, with significant risks of leukaemia (16.0 (9.1 to 26.0)); non-Hodgkin's lymphoma (16.8 (9.8 to 26.9)); and cancers of the colon $(3.2(1.4$ to 6.2$))$, lung $(3.8(2.6$ to 5.4$))$, bone $(15 \cdot 1(1.8$ to $54 \cdot 7))$, and thyroid (9.4 (1.1 to 33.9$)$ ).

risk of late recurrence has become relatively low. ${ }^{1}$ As a result the long term complications of treatment have become increasingly important. The risk of second cancers after radiation therapy is well known from studies of cancer patients treated by radiotherapy and from investigations of other groups exposed to radiation $^{23}$ : in essence, the risk of leukaemia is increased reaching a peak in the early years after exposure, and that of various solid tumours increases later. The risk of cancer after chemotherapy is less clear, however because the use of chemotherapy is more recent and many different therapeutic agents have been used. The relative risk of leukaemia is greatly increased in the early years after treatment with alkylating agents, ${ }^{4}$ but data on the risk of other tumours are limited. Recent summaries concluded that no excess of solid tumours has yet been shown, ${ }^{15}$ but clarification of the risk is needed to guide choice of treatment. Solid tumours account for most malignancies attributable to long term treatment with radiotherapy, and it is important to determine whether the same is true for chemotherapy.

This study used data collected by the British National Lymphoma Investigation on patients with Hodgkin's disease in the United Kingdom to investigate the risk of second primary cancers, with uniformly reviewed pathological diagnoses of Hodgkin's disease and of second primary lymphomas, and with a particular effort to obtain complete follow up.

nine years. It was increased substantially chemotherapy $(27.9(12.7$ to 52.9$))$, combined treatment with radiotherapy and chemotherapy $(21 \cdot 5(7.9)$ to 46.8)), and relative to number of courses of chemotherapy but was not significantly increased after radiotherapy $(2 \cdot 5(0 \cdot 1$ to $14 \cdot 1))$. Relative risk of non-Hodgkin's lymphoma increased in the first five years after treatment and remained high but showed no clear relation with type or extent of treatment. Relative risk of solid tumours was less raised initially but increased throughout follow up and for lung cancer 10 years or more after entry was $8 \cdot 3$ (4.0 to 15.3). The risk of solid tumours increased after treatments including radiotherapy and after chemotherapy alone. The risk after chemotherapy increased significantly with time since first treatment.

Conclusions-The risk of solid cancer, not of leukaemia, is the major long term hazard of treatment for Hodgkin's disease, and this seemed to apply after chemotherapy as well as after radiotherapy. These risks of second cancers are important in choice of treatment and in follow up of patients, but they are small compared with the great improvements in survival which have been brought about by modern therapeutic methods for Hodgkin's disease.

\section{Introduction}

The survival of patients with Hodgkin's disease has improved dramatically over the past 25 years, and the

\section{Patients and methods}

The British National Lymphoma Investigation is a collaborative group which has since 1970 collected detailed diagnostic, therapeutic, and follow up data on patients with lymphoma treated at over 60 participating centres in the United Kingdom. Most patients were entered into randomised clinical trials and the remainder were in other clinical studies, so the group has collected detailed treatment and regular follow up information for all patients.

This study was of patients aged 10 years and over who were first treated for Hodgkin's disease between February 1970, when the British National Lymphoma Investigation was initiated, and the end of December 1987. The diagnosis of Hodgkin's disease had in al cases been confirmed by the investigation's pathology panel.

Data were extracted from the investigation's files on all treatments, both at presentation and subsequently after relapses, including treatments received outside the investigation by patients who transferred to other centres. Treatments had not been received by the patients before entry as the investigation's protocols accept only previously untreated patients. For chemotherapy data were extracted on the drug combinations used in each course of treatment and the date each 
course was started. (A course described a fixed treatment regimen, usually used for about six months, after which the treatment was stopped.) For radiotherapy data were recorded on the overall dose (in Gy) for each course, the parts of the body irradiated, and the date of starting the course. Treatments (and person years at risk) after a second primary tumour had occurred were excluded from the analyses.

To ensure as complete follow up as possible several different methods were used. Firstly, consultants within the investigation conducted clinical follow up of their patients according to its protocols - that is, six monthly for the first five years and then annually, unless more frequent visits were needed for clinical reasons. Data on treatments, second cancers, and deaths were collected from forms sent at the above intervals to the consultants within the investigation; to other consultants, when applicable; and to general practitioners for patients discharged from hospital follow up and, if this failed, to the patients.

Some further cases were added to the files by the British National Lymphoma Investigation's pathology panel, who requests biopsy material from patients with apparent relapses of Hodgkin's disease and occasionally finds on review that these biopsies show second primary cancers.

In addition to these routine methods, each consultant was asked by letter to check that all second cancers known to him or her had been reported, and nine regional cancer registries in England and Wales checked their records for second cancers and deaths in the study patients. Some of the registries operate follow up systems, and these notified us also of the date of the last registry follow up. Finally, details for patients in whom follow up data were still incomplete were traced at the National Health Service central register, which includes virtually all residents of England and Wales and contains data on deaths, emigrations, and other losses to follow up (for example, entry to British military service overseas) and, since 1971, data on cancer registrations.

The pathological diagnoses of all second primary non-Hodgkin's lymphomas were reviewed by the pathology panel. The diagnosis by the referral centre's pathologist was accepted for secondary leukaemias and solid tumours, except in seven patients in whom a diagnosis was available only from a death certificate or clinical opinion. Site of cancer was coded to the ICD (eighth revision ${ }^{6}$ ) for 1970-8 data and to ICD (ninth revision $^{7}$ ) for 1979 onwards. Tumours not classified as malignant in the ICD (for example, cancer in situ of the cervix) were excluded.

\section{ANALYSIS OF DATA}

For analysis of treatment, the patients were separated into four groups according to treatments ever received for Hodgkin's disease: alkylating chemotherapy but never radiotherapy; ever alkylating chemotherapy and also at some time radiotherapy; extensive radiotherapy (that is, mantle or inverted Y or total nodal irradiation) but never alkylating chemotherapy; and local radiotherapy but no alkylating chemotherapy. Fifteen $(0.5 \%)$ patients whose type of chemotherapy was not fully recorded (14) or who had had only surgery (1) were omitted from this analysis.

TABLE I-Characteristics of patients by treatment category

\begin{tabular}{lccccc}
\hline Treatment & $\begin{array}{c}\text { No of } \\
\text { patients }\end{array}$ & $\begin{array}{c}\text { Mean age } \\
\text { (years) }\end{array}$ & $\begin{array}{c}\text { Male:female } \\
\text { ratio }\end{array}$ & $\begin{array}{c}\text { Person } \\
\text { years at risk }\end{array}$ & $\begin{array}{c}\text { Mean follow } \\
\text { up (years) }\end{array}$ \\
\hline Local radiotherapy & 376 & $35 \cdot 8$ & $1 \cdot 7: 1$ & $2309 \cdot 8$ & $6 \cdot 1$ \\
Extended radiotherapy & 559 & $34 \cdot 1$ & $1 \cdot 5: 1$ & $4420 \cdot 8$ & $7 \cdot 9$ \\
Alkylating chemotherapy & 987 & $38 \cdot 8$ & $1 \cdot 8: 1$ & $4613 \cdot 9$ & $4 \cdot 7$ \\
Alkylating chemotherapy plus radiotherapy & 909 & $33 \cdot 7$ & $1 \cdot 7: 1$ & $5911 \cdot 1$ & $6 \cdot 5$ \\
Total & 2846 & $35 \cdot 8$ & $1 \cdot 7: 1$ & $17328 \cdot 6$ & $6 \cdot 1$ \\
\hline
\end{tabular}

*Including 15 patients whose exact chemotherapy was not recorded or who had surgery alone.
Many different chemotherapeutic agents had been used at some time; for two agents, mustine and chlorambucil, data on their use as the sole alkylating agent were sufficient to allow separate analyses.

The risk of second cancers in the cohort was analysed to 31 December 1987 . Person years at risk by age, sex, and calendar year were calculated to that date or to death, loss to follow up, or incidence of a second primary cancer, if earlier. For analyses of risk in relation to time since first treatment, number of courses of treatment, number of alkylating agents, and combined treatment, person years at risk and second cancers in a patient at different stages of follow up were allocated to the stage of follow up at that time. Observed cancers in the patients were compared with expected cancers based on age specific, sex specific, and year specific rates for England and Wales. ${ }^{8}$ National cancer registration rates were not available in computer readable form for 1970 or $1985-7$, and therefore 1971 national data were used as the comparison for cancer incidence in the cohort in 1970-1, and 1984 data as the comparison for 1984-7. Significance of the observed to expected ratios (relative risks) was based on the Poisson distribution, with two sided $p$ values. Tests for trend were based on a likelihood ratio test statistic. Relative risks were adjusted for potential confounding variables by Poisson regression techniques ${ }^{910}$; the patients treated with local radiotherapy were taken as the baseline group for these analyses. Unadjusted analyses are presented in the tables and adjusted analyses are described in the text because the unadjusted analyses give uniformity of presentation and risks which relate directly to general population risks and also because some of the adjusted risk estimates would not converge (see below).

Absolute excess risks of second cancers by site were calculated by subtracting the expected from the observed numbers of cases and dividing by person years at risk. The cumulative (actuarial) probability of a second cancer occurring in a patient was calculated by the method of Kaplan and Meier. ${ }^{11}$

\section{Results}

During $1970-87,2853$ new patients aged 10 years or older with Hodgkin's disease entered the British National Lymphoma Investigation, comprising about a tenth of all patients with the disease incident in the United Kingdom during that time. Seven patients were excluded from our study because they died on the first day of treatment and therefore contributed no person days at risk. Table I shows the characteristics of the remaining 2846 patients by treatment group. Most $(63 \%)$ were male and most $(73 \%)$ were aged under 45 years at their first treatment for Hodgkin's disease. The mean duration of follow up was greatest for patients receiving extended radiotherapy and least for those receiving alkylating chemotherapy withou radiotherapy. During follow up 761 subjects died, 20 emigrated, and five were lost to follow up. A total of 17329 person years of follow up was accumulated in the cohort, mainly in the first five years $(10184)$ and second five years (5172) after first treatment started.

\section{RISKS OF SECOND PRIMARY CANCERS}

In all, 113 second primary cancers (other than Hodgkin's disease) occurred during follow up. One patient had a third primary cancer, of the lung, which was not included in the analysis. The overall relative risk of second primary cancer in the cohort was $2 \cdot 7$ (95\% confidence interval $2 \cdot 3$ to $3 \cdot 3$ ) compared with that expected for the general population, and the attributable risk was 41.4 per 10000 person years (table II). The relative risks were significantly increased for leukaemia $(16 \cdot 0 ; 9 \cdot 1$ to $26 \cdot 0)$, non- 
Hodgkin's lymphoma $(16 \cdot 8 ; 9 \cdot 8$ to $26 \cdot 9)$, colon cancer $(3.2 ; 1.4$ to $6 \cdot 2)$, lung cancer $(3.8 ; 2.6$ to $5 \cdot 4)$, bone cancer $(15 \cdot 1 ; 1 \cdot 8$ to $54 \cdot 7)$, and thyroid cancer $(9 \cdot 4 ; 1 \cdot 1$ to 33.9$)$. Fourteen of the 16 cases of leukaemia were acute myelocytic, one was acute lymphocytic, and one was myelodysplasia. Although the greatest relative risks were for lymphatic and haematopoietic malig nancies, their absolute risks were still low, and their life table probability of occurrence at each year of follow up was less than that for solid tumours (figure). The 15 year actuarial risk of second cancer overall was $11 \cdot 5 \%$, of solid tumours was $8 \cdot 5 \%$, of leukaemia was $1 \cdot 4 \%$, and of non-Hodgkin's lymphoma was $1 \cdot 5 \%$.

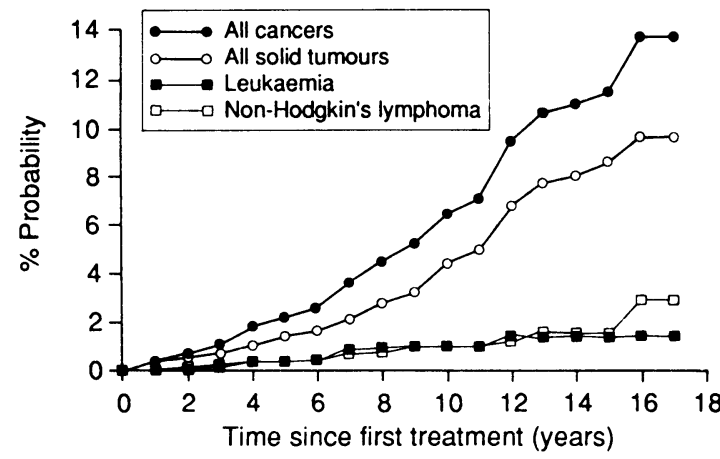

Cumulative (life table) probability of leukaemia, non-Hodgkin's lymphoma, and solid tumours in the patients

TABLE II $-R$ isks of second primary cancers of selected sites or types

\begin{tabular}{lccc}
\hline Site or type & $\begin{array}{c}\text { Observed/ } \\
\text { expected } \\
\text { cancers }\end{array}$ & $\begin{array}{c}\text { Relative risk } \\
\text { (95\% confidence interval) }\end{array}$ & $\begin{array}{c}\text { Attributable risk } \\
\text { per } 10000 \\
\text { person years }\end{array}$ \\
\hline Mouth and pharynx & $2 / 0 \cdot 5$ & $4 \cdot 4(0 \cdot 5$ to $15 \cdot 7)$ & 0.9 \\
Oesophagus & $2 / 0 \cdot 8$ & $2 \cdot 5(0 \cdot 3$ to $9 \cdot 0)$ & $0 \cdot 7$ \\
Stomach & $3 / 2 \cdot 2$ & $1 \cdot 3(0 \cdot 3$ to $3 \cdot 9)$ & $0 \cdot 4$ \\
Colon & $8 / 2 \cdot 5$ & $3 \cdot 2(1 \cdot 4 \text { to } 6 \cdot 2)^{\star \star}$ & $3 \cdot 2$ \\
Rectum & $2 / 1 \cdot 8$ & $1 \cdot 1(0 \cdot 1$ to $3 \cdot 9)$ & $0 \cdot 1$ \\
Larynx & $1 / 0 \cdot 5$ & $2 \cdot 0(0 \cdot 05$ to $10 \cdot 9)$ & $0 \cdot 3$ \\
Lung & $32 / 8 \cdot 4$ & $3 \cdot 8(2 \cdot 6 \text { to } 5 \cdot 4)^{\star \star \star}$ & $13 \cdot 6$ \\
Bone & $2 / 0 \cdot 13$ & $15 \cdot 2(1 \cdot 8 \text { to } 54 \cdot 7)^{\star}$ & $1 \cdot 1$ \\
Breast & $6 / 3 \cdot 8$ & $1 \cdot 6(0 \cdot 6$ to $3 \cdot 4)$ & $1 \cdot 2$ \\
Cervix & $2 / 1 \cdot 1$ & $1 \cdot 9(0 \cdot 2$ to $6 \cdot 8)$ & $1 \cdot 5$ \\
Prostate & $1 / 1 \cdot 6$ & $0 \cdot 6(0 \cdot 02$ to $3 \cdot 6)$ & $0 \cdot 6$ \\
Bladder & $3 / 2 \cdot 0$ & $1 \cdot 5(0 \cdot 3$ to $4 \cdot 5)$ & $1 \cdot 0$ \\
Thyroid & $2 / 0 \cdot 2$ & $9 \cdot 4(1 \cdot 1 \text { to } 33 \cdot 9)^{\star}$ & $9 \cdot 2$ \\
Non-Hodgkin's lymphoma & $17 / 1 \cdot 0$ & $16 \cdot 8(9 \cdot 8 \text { to } 26 \cdot 9)^{\star \star \star}$ & $8 \cdot 7$ \\
Leukaemia & $16 / 1 \cdot 0$ & $16 \cdot 0(9 \cdot 1 \text { to } 26 \cdot 0)^{\star \star \star \star}$ & $41 \cdot 4$ \\
All cancers except Hodgkin's disease & $113 / 41 \cdot 3$ & $2 \cdot 7(2 \cdot 3 \text { to } 3 \cdot 3)^{\star \star \star}$ & 4.4 \\
\hline
\end{tabular}

${ }^{\star} \mathrm{p}<0 \cdot 05,{ }^{\star \star} \mathrm{p}<0 \cdot 01,{ }^{\star \star \star} \mathrm{p}<0 \cdot 001$.

TABLE III-Relative risks of second primary cancers by years since first treatment
RISK BY TIME SINCE FIRST TREATMENT

The relative risk of leukaemia was over 10.0 in the first five years after initial treatment (table III) and reached a peak in the subsequent five years, before declining. The relative risk of non-Hodgkin's lymphoma was also greatly increased soon after treatment but without a subsequent decline during follow up. In contrast, the relative risk of lung cancer and of all other solid tumours (there being insufficient to analyse by site) increased steadily with duration of follow up. The increasing trend was significant for lung cancer and for second cancers overall. Consequently, from 10 years after first treatment the absolute excess risk of solid tumours associated with treatment $(71 \cdot 5 / 10000 /$ year) was three times that for leukaemia and non-Hodgkin's lymphoma (23.8/10 000/year).

\section{RISK BY TYPE OF TREATMENT}

The relative risk of leukaemia was far greater for patients treated with alkylating chemotherapy than with radiotherapy alone $(27.9$ (95\% confidence interval 12.7 to 52.9$)$ v $2.5(0 \cdot 1$ to $14 \cdot 1))$ but was not greater with combined treatment (alkylating agents plus radiotherapy) than with alkylating agents alone $(21 \cdot 5(7 \cdot 9$ to $46 \cdot 8) v 27 \cdot 9(12 \cdot 7$ to $52 \cdot 9)$ ) (table IV). Relative risks for non-Hodgkin's lymphoma were fairly similar after chemotherapy treatment, combined treatment, and radiotherapy overall $(18 \cdot 5(6 \cdot 8$ to 40.3$), 17 \cdot 6(5 \cdot 7$ to $41 \cdot 1)$, and $15 \cdot 0(5 \cdot 5$ to $32 \cdot 6)$ respectively), as were those for other solid tumours $(1.5(0.8$ to $2 \cdot 4), 1 \cdot 8(1.0$ to 3.0$)$, and $1.5(0.9$ to 2.4$)$ respectively) and lung cancer $(4 \cdot 2(2 \cdot 2$ to $7 \cdot 3), 4 \cdot 0(1 \cdot 8$ to $7 \cdot 6)$, and $3 \cdot 3(1 \cdot 7$ to $6 \cdot 0)$ respectively). Patients receiving combined treatment received on average almost as many cycles of chemotherapy as those treated solely with chemotherapy $(6.6 v 6.9)$ and also the same usual radiotherapy protocol (dose 35 Gy by mantle or inverted Y or total nodel irradiation, plus a further $5 \mathrm{~Gy}$ to the radiation field) as patients receiving radiotherapy.

When patients receiving extensive or local radiotherapy were considered separately a highly significant excess of non-Hodgkin's lymphoma was observed after local radiotherapy $(33.8(11.0$ to 78.8$))$ but not after extensive radiotherapy $(3.9(0 \cdot 1$ to $22 \cdot 0))$ (table IV). The only significant risks of particular solid tumours in relation to specific treatments were those for lung cancer shown in table IV; a relative risk of $52.6(1.3$ to

\begin{tabular}{|c|c|c|c|c|c|c|c|c|c|c|}
\hline \multirow[b]{2}{*}{$\begin{array}{l}\text { Duration of } \\
\text { follow up } \\
\text { (years) }\end{array}$} & \multicolumn{2}{|c|}{ Lung cancer } & \multicolumn{2}{|c|}{ All other solid tumours } & \multicolumn{2}{|c|}{ Leukaemia } & \multicolumn{2}{|c|}{ Non-Hodgkin's lymphoma } & \multicolumn{2}{|c|}{$\begin{array}{l}\text { All malignancies except } \\
\text { Hodgkin's disease }\end{array}$} \\
\hline & $\begin{array}{l}\text { Observed/ } \\
\text { expected }\end{array}$ & $\begin{array}{c}\text { Relative risk } \\
\text { (95\% confidence } \\
\text { interval) }\end{array}$ & $\begin{array}{l}\text { Observed/ } \\
\text { expected }\end{array}$ & $\begin{array}{c}\text { Relative risk } \\
\text { (95\% confidence } \\
\text { interval) }\end{array}$ & $\begin{array}{l}\text { Observed/ } \\
\text { expected }\end{array}$ & $\begin{array}{c}\text { Relative risk } \\
\text { (95\% confidence } \\
\text { interval) }\end{array}$ & $\begin{array}{l}\text { Observed/ } \\
\text { expected }\end{array}$ & $\begin{array}{c}\text { Relative risk } \\
\text { (95\% confidence } \\
\text { interval) }\end{array}$ & $\begin{array}{l}\text { Observed/ } \\
\text { expected }\end{array}$ & $\begin{array}{c}\text { Relative risk } \\
\text { (95\% confidence } \\
\text { interval) }\end{array}$ \\
\hline $0-4$ & $11 / 4 \cdot 7$ & $2 \cdot 4(1.2 \text { to } 4.2)^{\star \star}$ & $19 / 16 \cdot 3$ & $1.2(0.7$ to 1.8$)$ & $7 / 0 \cdot 6$ & $12 \cdot 6(5 \cdot 1 \text { to } 26 \cdot 0)^{\star \star \star \star}$ & $7 / 0 \cdot 5$ & $13 \cdot 2(5 \cdot 3 \text { to } 27 \cdot 2)^{\star \star \star}$ & $44 / 22 \cdot 3$ & $2.0(1.4 \text { to } 2.6)^{\star \star \star}$ \\
\hline $5-9$ & $11 / 2 \cdot 5$ & $4 \cdot 3(2 \cdot 2 \text { to } 7 \cdot 8)^{\star \star \star}$ & $19 / 9 \cdot 4$ & $2 \cdot 0(1.2 \text { to } 3 \cdot 1)^{\star \star}$ & $7 / 0 \cdot 3$ & $23 \cdot 2(9 \cdot 3 \text { to } 47 \cdot 7)^{\star \star \star \star}$ & $7 / 0 \cdot 3$ & $21.9(8.8 \text { to } 45.1)^{\star \star \star}$ & $44 / 12 \cdot 7$ & $3.5(2.5 \text { to } 4.6)^{\star \star \star}$ \\
\hline$\geqslant 10$ & $10 / 1 \cdot 2$ & $8 \cdot 3(4.0 \text { to } 15 \cdot 3)^{\star \star \star}$ & $10 / 4 \cdot 7$ & $2 \cdot 1(1.0 \text { to } 3.9)^{\star}$ & $2 / 0 \cdot 1$ & $14 \cdot 1(1.7 \text { to } 50 \cdot 9)^{\star}$ & $3 / 0 \cdot 2$ & $18.6(3.8 \text { to } 54.4)^{\star \star \star}$ & $25 / 6 \cdot 2$ & $4.0(2.6 \text { to } 5.9)^{\star \star \star}$ \\
\hline & $32 / 8 \cdot 4$ & $3.8(2.6 \text { to } 5 \cdot 4)^{\star \star \star}$ & $48 / 30 \cdot 5$ & $1 \cdot 6(1 \cdot 2 \text { to } 2 \cdot 1)^{\star \star}$ & $16 / 1 \cdot 0$ & $16 \cdot 0(9 \cdot 1 \text { to } 26 \cdot 0)^{\star \star \star}$ & $17 / 1 \cdot 0$ & $16.8(9.8 \text { to } 26.9)^{\star \star \star}$ & $113 / 41 \cdot 3$ & $2 \cdot 7(2 \cdot 3 \text { to } 3 \cdot 3)^{\star \star \star \star}$ \\
\hline$\chi^{2}$ linear trend $(\mathrm{df}=1)$ & & $8 \cdot 8^{\star \star}$ & & 3.4 & & 0.3 & & 0.5 & & $10 \cdot 2^{\star \star}$ \\
\hline
\end{tabular}

${ }^{\star} \mathrm{p}<0 \cdot 05,{ }^{\star \star} \mathrm{p}<0 \cdot 01,{ }^{\star \star \star} \mathrm{p}<0 \cdot 001$.

TABLE IV-Relative risks of second primary cancers by type of treatment

\begin{tabular}{|c|c|c|c|c|c|c|c|c|c|c|}
\hline \multirow[b]{2}{*}{ Treatment } & \multicolumn{2}{|c|}{ Lung cancer } & \multicolumn{2}{|c|}{ All other solid tumours } & \multicolumn{2}{|c|}{ Leukaemia } & \multicolumn{2}{|c|}{ Non-Hodgkin's lymphoma } & \multicolumn{2}{|c|}{$\begin{array}{c}\text { All malignancies except } \\
\text { Hodgkin's disease }\end{array}$} \\
\hline & $\begin{array}{l}\text { Observed/ } \\
\text { expected }\end{array}$ & $\begin{array}{c}\text { Relative risk } \\
\text { (95\% confidence } \\
\text { interval) }\end{array}$ & $\begin{array}{l}\text { Observed/ } \\
\text { expected }\end{array}$ & $\begin{array}{c}\text { Relative risk } \\
(95 \% \text { confidence } \\
\text { interval) }\end{array}$ & $\begin{array}{l}\text { Observed/ } \\
\text { expected }\end{array}$ & $\begin{array}{c}\text { Relative risk } \\
\text { (95\% confidence } \\
\text { interval) }\end{array}$ & $\begin{array}{l}\text { Observed/ } \\
\text { expected }\end{array}$ & $\begin{array}{c}\text { Relative risk } \\
\text { (95\% confidence } \\
\text { interval) }\end{array}$ & $\begin{array}{l}\text { Observed/ } \\
\text { expected }\end{array}$ & $\begin{array}{c}\text { Relative risk } \\
\text { (95\% confidence } \\
\text { interval) }\end{array}$ \\
\hline \multirow{3}{*}{$\begin{array}{l}\text { Alkylating } \\
\text { chemotherapy } \\
\text { Alkylating } \\
\text { chemotherapy } \\
\text { plus } \\
\text { radiotherapy }\end{array}$} & $12 / 2 \cdot 9$ & $4 \cdot 2(2 \cdot 2 \text { to } 7 \cdot 3)^{\star \star \star}$ & $15 / 10 \cdot 2$ & $1.5(0.8$ to $2 \cdot 4)$ & $9 / 0 \cdot 3$ & $27.9(12.7 \text { to } 52.9)^{\star \star \star}$ & $6 / 0 \cdot 3$ & $18 \cdot 5(6.8 \text { to } 40 \cdot 3)^{\star \star \star}$ & $42 / 13 \cdot 8$ & $3 \cdot 0(2 \cdot 2 \text { to } 4 \cdot 1)^{\star \star \star}$ \\
\hline & & & & & & & & , & & \\
\hline & $9 / 2 \cdot 2$ & $4.0(1.8 \text { to } 7 \cdot 6)^{\star \star \star}$ & $15 / 8 \cdot 3$ & $1.8(1.0 \text { to } 3.0)^{\star}$ & $6 / 0 \cdot 3$ & $21.5(7.9 \text { to } 46.8)^{\star \star \star}$ & $5 / 0 \cdot 3$ & $17 \cdot 6(5 \cdot 7 \text { to } 41 \cdot 1)^{\star \star \star}$ & $35 / 11 \cdot 2$ & $3 \cdot 1(2 \cdot 2 \text { to } 4 \cdot 4)^{\star \star \star \star}$ \\
\hline Radiotherapy & $11 / 3 \cdot 3$ & $3 \cdot 3(1 \cdot 7 \text { to } 6 \cdot 0)^{\star \star \star}$ & $18 / 12 \cdot 0$ & $1.5(0.9$ to 2.4$)$ & $1 / 0 \cdot 4$ & $2 \cdot 5(0 \cdot 1$ to $14 \cdot 1)$ & $6 / 0 \cdot 4$ & $15 \cdot 0(5 \cdot 5 \text { to } 32 \cdot 6)^{\star \star \star}$ & $36 / 16 \cdot 2$ & 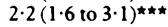 \\
\hline Extensive & $8 / 2 \cdot 0$ & $3.9(1.7 \text { to } 7 \cdot 8)^{\star \star}$ & $14 / 7 \cdot 5$ & $1.9(1.0 \text { to } 3 \cdot 1)^{\star}$ & $0 / 0 \cdot 2$ & & $1 / 0 \cdot 2$ & $3.9(0.1$ to $22 \cdot 0)$ & $23 / 10 \cdot 1$ & $2.3(1.4 \text { to } 3.4)^{\star \star \star \star}$ \\
\hline Local & $3 / 1 \cdot 3$ & $2.3(0.5$ to 6.9$)$ & $4 / 4 \cdot 5$ & $0.9(0.2$ to 2.3$)$ & $1 / 0 \cdot 1$ & $6.8(0.2$ to 37.9$)$ & $5 / 0 \cdot 1$ & $33.8(11.0 \text { to } 78.8)^{\star \star \star}$ & $13 / 6 \cdot 1$ & $2.1(1.1 \text { to } 3.6)^{\star}$ \\
\hline
\end{tabular}


293.3) for bone cancer after local radiotherapy, based on only one case; and a relative risk of $4 \cdot 0(1 \cdot 1$ to $10 \cdot 2)$ for breast cancer after extensive radiotherapy. The relative risk of colon cancer was increased in each treatment group, but not significantly. Of the 53 solid tumours in patients who had received any radiotherapy, 28 occurred within the radiation fields and 14 outside; for 11 tumours this could not be determined exactly. All five breast cancers in patients with any radiotherapy treatment occurred within the radiation fields, and all seven colorectal cancers in such patients occurred outside the fields.

For 15 of the 32 patients with lung cancer, information on smoking was available from the case notes: two were stated to be non-smokers and 13 smokers (including for patients for whom smoking status was known, all six patients receiving radiotherapy, two of the three receiving combined treatment, and five of the six receiving chemotherapy alone).

\section{RISK BY TIME SINCE FIRST TREATMENT AND TREATMENT} TYPE

Adjusting the relative risks in each treatment group in table IV for period since first treatment to control for its potentially confounding effect did not materially alter the findings. The adjustment slightly increased or left unchanged the relative risks in the chemotherapy and combined treatment groups and slightly decreased the risks in the patients receiving extended radiotherapy in comparison to those receiving local radiotherapy.

Examination of risks in each treatment group by time since first treatment was limited by small numbers in many of the subcategories. For leukaemia the patterns of relative risk over time after chemotherapy and combined treatment were similar to the pattern for the cohort overall; after radiotherapy there were insufficient data for analysis. Relative risks by time since radiotherapy and combined treatment for nonHodgkin's lymphoma were inconsistent, based on small numbers. Relative risks for solid tumours decreased non-significantly with time after entry for local radiotherapy, increased non-significantly with time after extended radiotherapy, and increased significantly with time after chemotherapy and after combined treatment (table V).

\section{RISK BY COURSES OF TREATMENT}

Relative risks of second cancer overall and of leukaemia were significantly greater in patients who had received multiple courses rather than one course of treatment (table VI). A similar but not significant tendency was observed for lung cancer and nonHodgkin's lymphoma. Adjustment for time since first treatment left these risks virtually unchanged. Similar analyses by type of treatment (table VI) were limited by small numbers of person years for patients receiving multiple courses of treatment, and we therefore aggregated some tumour groups for this analysis. In patients who had received radiotherapy but no chemotherapy the relative risks of solid tumours, non-Hodgkin's lymphoma, and all tumours were greater, but not significantly so, after multiple courses rather than a single course of treatment (data on leukaemia were insufficient for comment). In patients who had received only chemotherapy the relative risk of leukaemia was significantly greater for multiple courses than a single course of treatment; relative risks of non-Hodgkin's lymphoma and of all tumours were non-significantly greater after multiple courses than a single course of treatment and risk of solid tumours non-significantly greater after a single rather than multiple courses. Adjustment of these risks for time since first treatment made little difference.

\section{RISK BY USE OF ALKYLATING AGENTS}

Table VII shows the relative risks in relation to certain alkylating agents. There was greater risk of secondary primary cancers overall and of site grouping except "other solid tumours" after treatment with mustine than chlorambucil. The greatest relative risk of second primary cancers, however, was in patients who had received more than one alkylating agent, as a consequence of a very high risk of haematopoietic tumours but not solid tumours after treatment with multiple alkylating agents. There were insufficient subjects to analyse risk separately for particular combinations of alkylating agents, but the high overall risk after treatment with multiple agents did not seem to depend solely on combinations which included mustine. Adjustment of these analyses for duration since first treatment and number of courses of treatment increased the risk of second primary cancers after

TABLE $\mathrm{v}-$ Relative risks of solid second primary cancers by type of treatment and time since first treatment

\begin{tabular}{|c|c|c|c|c|c|c|c|}
\hline \multirow[b]{3}{*}{ Treatment } & \multicolumn{6}{|c|}{ Years since first treatment } & \multirow[b]{3}{*}{$\begin{array}{l}\chi^{2} \text { linear trend } \\
\quad(\mathrm{df}=1)\end{array}$} \\
\hline & \multicolumn{2}{|r|}{$0-4$} & \multicolumn{2}{|r|}{$5-9$} & \multicolumn{2}{|r|}{$\geqslant 10$} & \\
\hline & $\begin{array}{l}\text { Observed/ } \\
\text { expected }\end{array}$ & $\begin{array}{c}\text { Relative risk } \\
\text { (95\% confidence } \\
\text { interval) }\end{array}$ & $\begin{array}{l}\text { Observed/ } \\
\text { expected }\end{array}$ & $\begin{array}{c}\text { Relative risk } \\
\text { (95\% confidence } \\
\text { interval) }\end{array}$ & $\begin{array}{l}\text { Observed/ } \\
\text { expected }\end{array}$ & $\begin{array}{c}\text { Relative risk } \\
\text { (95\% confidence } \\
\text { interval) }\end{array}$ & \\
\hline $\begin{array}{l}\text { Alkylating chemotherapy } \\
\text { Alkylating chemotherapy }\end{array}$ & $10 / 8 \cdot 2$ & $1.2(0.6$ to $2 \cdot 2)$ & $11 / 3 \cdot 4$ & $3.2(1.6 \text { to } 5.8)^{\star \star \star}$ & $6 / 1 \cdot 4$ & $4 \cdot 2(1 \cdot 5 \text { to } 9 \cdot 1)^{\star \star}$ & $8 \cdot 0^{\star \star}$ \\
\hline plus radiotherapy & $8 / 5 \cdot 6$ & $1.4(0.6$ to 2.8$)$ & $9 / 3 \cdot 4$ & $2.6(1.2 \text { to } 4.9)^{\star}$ & $7 / 1 \cdot 5$ & $4.8(1.9 \text { to } 9.8)^{\star \star}$ & $5 \cdot 7^{\star}$ \\
\hline Extensive radiotherapy & $8 / 4 \cdot 3$ & $1.9(0.8$ to 3.7$)$ & $8 / 3 \cdot 3$ & $2 \cdot 4(1.0 \text { to } 4.8)^{\star}$ & $6 / 2 \cdot 0$ & $3 \cdot 1(1 \cdot 1 \text { to } 6 \cdot 7)^{\star}$ & $0 \cdot 9$ \\
\hline Local radiotherapy & $4 / 2 \cdot 9$ & $1.4(0.4$ to 3.5$)$ & $2 / 1 \cdot 8$ & $1 \cdot 1(0 \cdot 1$ to $3 \cdot 9)$ & $1 / 1 \cdot 0$ & $1.0(0 \cdot 02$ to $5 \cdot 4)$ & $0 \cdot 1$ \\
\hline
\end{tabular}

TABLE VI - Relative risks of second primary cancers by number of courses of treatment

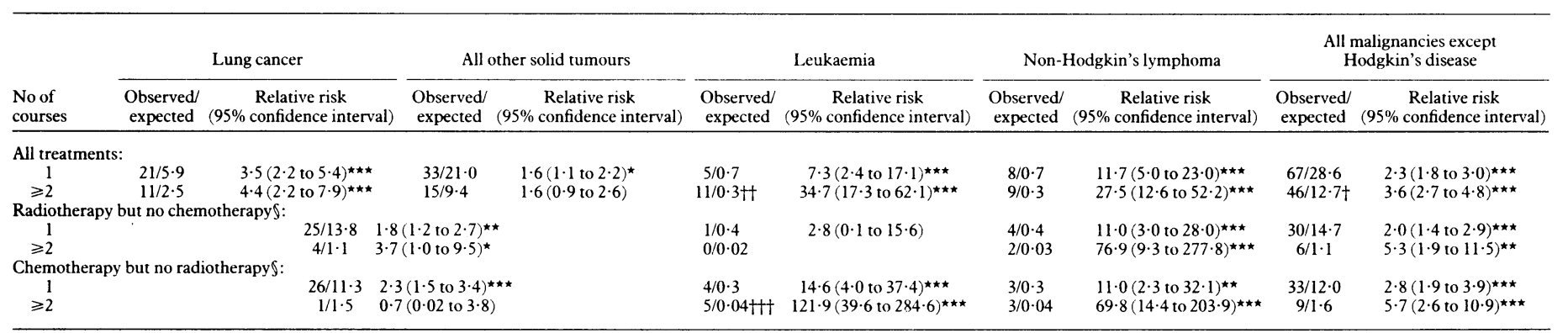

${ }^{\star} \mathrm{p}<0 \cdot 05,{ }^{\star \star} \mathrm{p}<0 \cdot 01,{ }^{\star \star \star} \mathrm{p}<0 \cdot 001$.

Difference between group receiving one course of treatment and group receiving two or more courses of treatments: $\nmid p<0 \cdot 05, \dagger p<0.01, \dagger+p<0 \cdot 001$

§Lung cancer and all other solid tumours combined. 


\begin{tabular}{|c|c|c|c|c|c|c|c|c|c|c|}
\hline \multirow[b]{2}{*}{ Treatment } & \multicolumn{2}{|c|}{ Lung cancer } & \multicolumn{2}{|c|}{ Other solid tumours } & \multicolumn{2}{|r|}{ Leukaemia } & \multicolumn{2}{|c|}{ Non-Hodgkin's lymphoma } & \multicolumn{2}{|c|}{$\begin{array}{l}\text { All malignancies except } \\
\text { Hodgkin's disease }\end{array}$} \\
\hline & $\begin{array}{c}\text { Observed/ } \\
\text { expected }\end{array}$ & $\begin{array}{c}\text { Relative risk } \\
\text { (95\% confidence } \\
\text { interval) }\end{array}$ & $\begin{array}{c}\text { Observed/ } \\
\text { expected }\end{array}$ & $\begin{array}{c}\text { Relative risk } \\
\text { (95\% confidence } \\
\text { interval) }\end{array}$ & $\begin{array}{c}\text { Observed/ } \\
\text { expected }\end{array}$ & $\begin{array}{c}\text { Relative risk } \\
\text { (95\% confidence } \\
\text { interval) }\end{array}$ & $\begin{array}{c}\text { Observed/ } \\
\text { expected }\end{array}$ & $\begin{array}{c}\text { Relative risk } \\
\text { (95\% confidence } \\
\text { interval) }\end{array}$ & $\begin{array}{l}\text { Observed/ } \\
\text { expected }\end{array}$ & $\begin{array}{c}\text { Relative risk } \\
(95 \% \text { confidence } \\
\text { interval) }\end{array}$ \\
\hline \multirow{3}{*}{$\begin{array}{l}\begin{array}{l}\text { Mustine alone } \\
(n=424)\end{array} \\
\text { Chlorambucil } \\
\text { alone }(n=402) \\
\geqslant \text { Alkylating agent } \\
\quad(n=302)\end{array}$} & $10 / 2 \cdot 0$ & $5.0(2 \cdot 4 \text { to } 9 \cdot 1)^{\star \star \star}$ & $10 / 7 \cdot 0$ & $1.4(0.7$ to $2 \cdot 6)$ & $5 / 0 \cdot 2$ & $22 \cdot 9(7.4 \text { to } 53.5)^{\star \star \star}$ & $3 / 0 \cdot 2$ & $14 \cdot 2(2 \cdot 9 \text { to } 41 \cdot 5)^{\star \star}$ & $28 / 9 \cdot 5$ & $2.9(1.9 \text { to } 4.2)^{\star \star \star}$ \\
\hline & $1 / 0 \cdot 5$ & $1.9(0.05$ to 10.6$)$ & $3 / 2 \cdot 0$ & $1.5(0.3$ to 4.4$)$ & $0 / 0 \cdot 06$ & & $0 / 0 \cdot 07$ & & $4 / 2 \cdot 7$ & $11.5(0.4$ to 3.8$)$ \\
\hline & $3 / 0 \cdot 6$ & $5 \cdot 5(1 \cdot 1 \text { to } 16 \cdot 0)^{\star}$ & $3 / 2 \cdot 0$ & $1.5(0.3$ to 4.4$)$ & $6 / 0 \cdot 07$ & $82 \cdot 2(30 \cdot 2 \text { to } 178 \cdot 9)^{\star \star \star}$ & $4 / 0 \cdot 07$ & $53.3(14.5 \text { to } 136.5)^{\star \star \star}$ & $16 / 2 \cdot 7$ & $5.9(3.4 \text { to } 9.6)^{\star \star \star}$ \\
\hline
\end{tabular}

treatment with chlorambucil compared with mustine (from $0.5(0.2$ to 1.5$)$ to $0.8(0.3$ to 2.4$)$ ) and after treatment with multiple alkylating agents compared with mustine (from $1.9(1.0$ to 3.6$)$ to $5 \cdot 8(0 \cdot 7$ to $44 \cdot 7)$ ); the latter increase seems large, but is from a significant to a non-significant raised risk, reflecting instability of the adjusted risk estimate. For most of the site specific risks adjusted relative risk estimates could not be calculated by the method used (the estimates would not converge).

\section{Discussion}

The study showed different patterns of risk of leukaemia, non-Hodgkin's lymphoma, and solid tumours after treatment. The much increased relative risk of leukaemia after alkylating chemotherapy for Hodgkin's disease has been known since early in its use $^{12}$ and has been shown repeatedly in epidemiological studies of patients with Hodgkin's disease, ${ }^{413-16}$ in patients treated for other cancers, ${ }^{14}$ and in a casecontrol study of some aspects of leukaemia risk in patients in the British National Lymphoma Investigation. ${ }^{17}$ The increased risk has been shown specifically for acute non-lymphocytic leukaemias; we calculated risks for leukaemias overall because not all leukaemias in the comparison (national) data set were classified by acuteness and histological subtype. As 14 of the 16 cases of leukaemia observed in our follow up were of acute non-lymphocytic leukaemia, however, the relative risks for this category would clearly be much higher than those presented.

Notably, as in previous studies of patients with Hodgkin's disease, ${ }^{13} 141618$-20 the relative risk of leukaemia was not appreciably increased in patients treated with radiotherapy alone whereas some other exposed groups (for example, early radiologists ${ }^{21}$ and radium dial workers ${ }^{22}$ ) were at a much increased risk of leukaemia. Similar findings to ours were noted after radiation treatment of other patient groups and were attributed to cell killing by high dose radiation. ${ }^{23} 24$

Early concern that combined treatment might be particularly leukaemogenic ${ }^{12}$ was not confirmed by our data: the relative risk of leukaemia was no greater after combined treatment than after chemotherapy alone, confirming other findings. ${ }^{413151620}$ Our data add to evidence that chlorambucil is no more leukaemogenic than mustine, ${ }^{25}$ which is important given the lesser acute toxicity and favourable efficacy of chlorambucil. $^{25}{ }^{26} \mathrm{We}$ also did not find.a greater risk of solid tumours after treatment with chlorambucil than mustine. Given the short follow up for most chlorambucil patients, however, interpretation must be tentative.

The pattern of relative risk of leukaemia with time after chemotherapy was similar to that after radiation exposures ${ }^{3}-a$ peak occurred five to nine years after treatment, with risk declining but not entirely subsiding thereafter. It has been claimed that the increased risk of leukaemia in patients with Hodgkin's disease ceases beyond 10 years, ${ }^{27}$ but we found, as did van Leeuwen $e t a l^{16}$ and Kaldor et $a l,{ }^{4}$ that the risk was substantially increased at 10 years and beyond.
The time course of the increased risk of leukaemia after Hodgkin's disease, the difference in risk between treatments, the dose-response relation for chemotherapy, and the results of animal experiments ${ }^{28} 29$ all suggest that the excess risk relates to treatment rather than to Hodgkin's disease itself.

\section{RISK OF NON-HODGKIN'S LYMPHOMA}

The raised risk of non-Hodgkin's lymphoma after Hodgkin's disease is more difficult to interpret. We found no appreciable variation in relative risk with time since treatment and no significant increase with number of courses of treatment. Relative risk was also similar for the different treatments, except for particularly high risk after local radiotherapy and after multiple alkylating agents. Previous data showed no consistent pattern on these issues (except that, as in our data, risk increased early after treatment and throughout follow up). ${ }^{5} 152930$ Part of this inconsistency might reflect diagnostic misclassification in some studies (that is, recurrences of Hodgkin's disease might have been misdiagnosed as non-Hodgkin's lymphoma or the initial primary tumour might have been misdiagnosed as Hodgkin's disease when it was non-Hodgkin's lymphoma or a composite lymphoma). This should not have occurred with our data as all diagnoses of primary Hodgkin's disease and of second non-Hodgkin's lymphoma ${ }^{31}$ were reviewed (by MHB, KAMcL) before inclusion. Inconsistency between studies might also be due to some extent to pathologists' differing diagnostic criteria for Hodgkin's disease and non-Hodgkin's lymphoma and for distinguishing between them.

Non-Hodgkin's lymphoma might be a consequence of treatment of Hodgkin's disease, but if so, the risk does not seem to differ clearly by type of treatment currently available and therefore is not an important consideration in choice of treatment. Alternatively, the risk may be a rare part of the natural course of Hodgkin's disease or an effect of Hodgkin's disease itself. For instance, it might result from the immunosuppression that is present at diagnosis of Hodgkin's disease and persists after treatment ${ }^{32}$ : greatly increased risk of non-Hodgkin's lymphoma is a particular feature of several groups of immunosuppressed subjects. ${ }^{33}$ Finally, the inconsistencies in the risk of non-Hodgkin's lymphoma between studies and subgroups suggest that more than one of the above mechanisms may be active, with different overall balances of effect in different groups.

\section{RISKS OF SITE SPECIFIC SOLID CANCERS}

The increased risks of site specific solid cancers we found generally accord with those seen previously in patients with Hodgkin's disease. A significant relative risk of lung cancer was seen previously. ${ }^{15162029}$ The relative risk of colon cancer, which was significantly increased in our study, showed a non-significant increase previously ${ }^{152}$ and that of breast cancer, although not significant in our data, was similar in magnitude to that seen previously. ${ }^{1529}$ In our cohort there were no cases of salivary gland cancer, soft tissue cancer, or melanoma, which have shown striking excess risks in some previous studies of patients with 
Hodgkin's disease..$^{5152029}$ These are uncommon tumours, however, for which expected numbers were low $(0 \cdot 10,0 \cdot 24$, and 0.66 respectively), and hence the results were compatible with sizable risks.

The sites at which the risk of solid second cancers was increased are ones for which radiation carcinogenesis is well established. ${ }^{3}$ The significant relative risks for lung cancer and other solid tumours after radiotherapy in this cohort are therefore as expected. The increased risk of solid tumours after chemotherapy is of much greater interest, however, as risks were not found to be increased in certain previous studies despite experimental data in animals indicating a wide range of solid tumours resulting from use of cytotoxic drugs ${ }^{29}$ and concern that in humans the effect of alkylating agents may resemble that of radiation for solid malignancies, as it does for leukaemia.

The risk of bladder cancer is increased in humans after cyclophosphamide ${ }^{28}$ and chlornaphazine ${ }^{34}$ treatments and so is that of some solid tumours after azathioprine, ${ }^{28}$ but whether chemotherapy otherwise causes solid malignancies is not clear..$^{29} \mathrm{~A}$ meta-analysis of treatment for Hodgkin's disease in 1988 found that the risk of solid tumours was not increased overall or significantly for any specific site after alkylating chemotherapy. ${ }^{5}$ A recent review concluded that the incidence of solid tumours had not been found to be increased after chemotherapy alone. ${ }^{1}$ Our data, however, showed a substantial and significantly increased risk of solid tumours after chemotherapy. This occurred several years after first treatment, and therefore the extent of follow up available in the study was important in its demonstration. The pattern of relative risk of solid tumours by time after chemotherapy was similar to that in major cohorts exposed to radiation in that it increased less rapidly than that for leukaemia and continued to increase after the risk of leukaemia had ceased to do so. ${ }^{16-24}$ The risk of solid tumours was not greater after multiple than a single course of chemotherapy, but person years for multiple courses were few and the confidence limits correspondingly wide. If the risk of solid tumours after alkylating chemotherapy continues with longer follow up to resemble that for radiation induced solid tumours then, particularly with the increasing survival of young patients with Hodgkin's disease, the future absolute risks of these tumours may be very large and constitute a major hazard of alkylating chemotherapy.

The interactions of the carcinogenic effect of a treatment with the effects of other risk factors are of practical as well as theoretical importance. One potential interaction is between different treatments. Use of more than one alkylating agent seemed to increase the risk of a second cancer. Surprisingly, however, radiotherapy and chemotherapy combined did not show a greater risk than either alone despite exposure to about the same dose of each in combination as when used singly. Cell killing by high dose radiotherapy might explain the lack of greater risk of leukaemia after combined treatment than after chemotherapy but would not obviously explain the behaviour of solid tumours, for which radiotherapy alone produced a substantially increased risk in our (and previous) data. Nevertheless, the data suggested the possibility that some inhibition of carcinogenesis might occur through use of both agents. We will analyse elsewhere whether the order of treatment affects risk. Splenectomy may also affect the risk, ${ }^{416}$ and this will be analysed elsewhere.

A second potentially important interaction is between smoking and treatment. As in previous studies $^{1516}$ we had insufficient data on smoking to calculate the risk of lung cancer in relation to both agents. In other contexts radiation and smoking seem to have at least an additive effect on the risk of lung cancer $^{35}$ so a particular effort to dissuade patients with Hodgkin's disease from smoking would seem prudent until satisfactory data are available.

\section{POTENTIAL BIAS}

The large relative risks of second cancers found in the study are not plausibly explained by bias, artefact, or chance, but potential biases may have had some effect. The patients were under close medical surveillance and therefore cancers might have been found earlier than in the general population and some cancers, particularly those of a relatively benign nature, might have been detected which otherwise might not have been diagnosed. Only five of the second cancers, however, were found in the first six months after entry to risk (when any accumulation of undetected tumours from before presentation of Hodgkin's disease might have been detected), suggesting that this effect, if any, was small. The apparent risks of second primary cancer might also be slightly inflated because of the effort made to ascertain from multiple sources all such tumours diagnosed in the study patients whereas the expected numbers of cancers came from routine cancer registration data, which are inevitably somewhat in complete. Such effects might explain a small increase in apparent risk in the cohort but not the severalfold risks found. Estimated risks might have been diminished by including in the analyses the follow up period immediately after first treatment, before completion of the minimum induction period (were it known) of carcinogenesis by treatment. As the induction period is not known we chose not to omit an arbitrary early period from the analyses, but the effect of omitting, say, the first year, as in some other studies, would have been small.

Another potential artefact might be confounding of the results by aetiological host or environmental factors for both Hodgkin's disease and the second cancer. For instance, because patients with Hodgkin's disease are on average of high social class they might be expected to have slightly atypical risks for many cancers (for example, increased risk of breast cancer, decreased risk of stomach cancer) because of social class related behaviours. Also the presence of Hodgkin's disease may alter behaviours affecting risk of cancer-for instance, delaying or excluding childbearing-which itself would increase risk of breast cancer. However, such effects, at least for known risk factors, would be modest compared with the large risks we showed.

Despite the risks found in the study, the issue of treatment induced second primary cancers remains relatively small compared with the dramatic increase which has occurred in survival in Hodgkin's disease. The results suggest, however, that with longer survival the late risks of solid cancers may become substantial and that patients with Hodgkin's disease need continued follow up to detect second cancers rapidly. The sizable lung cancer risk suggests that they particularly should be persuaded not to smoke. Further comparisons of the risk of second cancers, particularly of solid tumours, between different treatments are needed to guide development of treatment protocols which minimise these effects.

We thank the collaborators in the British National Lymphoma Investigation whose patients are included in this analysis; the Lymphoma Research Trust, the Cancer Research Campaign, the Lisa Lear Fund, and the Isle of Man Anticancer Association for financial help to the British National Lymphoma Investigation; the Office of Population Censuses and Surveys and the regional cancer registries in England and Wales for tracing patients; Professor P G Smith for advice; and Miss J Bonner for secretarial help.

\footnotetext{
1 Young RC, Bookman MA, Longo DL. Late complications of Hodgkin's diseasse management. I Natl Cancer Inst Monogr 1990;10:55-60.
}

2 Boice JD Jr, Fraumeni JF Jr, eds. Radiation carcinogenesis: epidemiology 
and biological significance. New York: Raven Press, 1984. (Progress in cancer research and therapy. Vol 26 .

3 National Research Council. Health effects of exposure to low levels of ionizin radiation. BEIR V. Washington, DC: National Academy Press, 1990.

4 Kaldor JM, Dav NE, Clarke EA, Van Leeuwen FE, Henry-Amar $M$ Fiorentino MV, et al. Leukemia following Hodgkin's disease. $N$ Engl f Med 1990:322:7-13.

5 Boivin J-F, O'Brien K. Solid cancer risk after treatment of Hodgkin's disease. Cancer 1988;61:2541-6.

6 World Health Organisation. Manual of the international statistical classification of diseases, injuries, and causes of death. 8th revision. Geneva: WHO, 1967.

7 World Health Organisation. Manual of the international statistical classification of diseases, injuries, and causes of death. 9th revision. Geneva: WHO, 1977.

8 Coleman M, Douglas A, Hermon C. Cohort study analyses with a FORTRAN computer program. Int f Epidemiol 1986;15:134-7.

9 Breslow NE, Day NE. Statistical methods in cancer research. Vol II. The design and analysis of cohort studies. Lyons: International Agency for Research o Cancer, 1987. (IARC scientific publication No 82 .)

10 Statistics and Epidemiology Research Corporation. EGRET. Seattle: SERC 1989.

11 Kaplan EL, Meier P. Non-parametric estimation from incomplete observations. Foumal of the American Statistical Association 1958;53:457-81.

12 Coleman CN, Williams CJ, Flint A, Glatstein EJ, Rosenherg SA, Kaplan HS. Hematologic neoplasia in patients treated for Hodgkin's disease. NEngl F Med 1977;297:1249-52.

13 Boivin J-F, Hutchison GB, Lyden M, Godbold J, Chorosh J, Schottenfeld D. Second primary cancers following treatment of Hodgkin's disease. $N$ NalCancer lnst 1984,72:233-41.

14 Pedersen-Bjegaard J, Specht L, Larsen SO, Ersbøll J, Struck J, Hansen MM, et al. Risk of therapy-related leukaemia and pre-leukaemia after Hodgkin's disease. Relation to age, cumulative dose of alkylating agents, and time from chemotherapy. Lancet 1987 ;ii:83-8.

15 Tucker MA, Coleman CN, Cox RS, Varghese A, Rosenberg SA. Risk of second cancers after treatment for Hodgkin's disease. $N$ Engl $\mathcal{F}$ Med 1988; $318: 76-81$.

16 Van Leeuwen FE, Somers R, Taal BG, Van Heerde P, Coster B, Dozeman T, et al. Increased risk of lung cancer, non-Hodgkin's lymphoma, and leukemia following Hodgkin's disease. 7 Clin Oncol 1989;7: 1046-58.

17 Devereux S, Selassie TG, Vaughan Hudson G, Vaughan Hudson B, Linch The DC. Leukaemia complicating treatment for Hodgkin's disease: the expe ence of the

18 Tester WJ, Kinsella TJ, Waller B, Makuch RW, Kelley PA, Glatstein E, et ol. Second malignant neoplasms complicating Hodgkin's disease: the National Second malignant neoplasms complicating Hodgkin's

19 Valagussa P, Santoro A, Fossati-Bellani F, Banfi A, Bonadonna G. Second acute leukemia and other malignancies following treatment for Hodgkin's disease. $\mathcal{F}$ Clin Oncol 1986;4:830-7.

20 Colman M, Easton DF, Horwich A, Peckham MJ. Second malignancies and Hodgkin's disease - the Royal Marsden Hospital experience. Radiother Oncol 1988;11:229-38.
21 Smith PG, Doll R. Mortality from cancer and all causes among British radiologists. Br f Radiol 1981;54:187-94.

22 Polednak AP, Stehney AF, Rowland RE. Mortality among women firs employed before 1930 in the US radium dial-painting industry. A group ascertained from employment lists. Am f E Eidemiol 1978;107:179-95.

23 Smith PG. Leukemia and other cancers following radiation treatment of pelvic disease. Cancer 1977;39:1901-5.

24 Day NE, Boice JD Jr. Summary chapter. In: Second cancer in relation to radiation treatment for cervical cancer. Lyons: International Agency for Research on Cancer; 1983;137-81. (IARC scientific publication No 52.)

25 Selby P, Patel P, Milan S, Meldrum M, Mansi J, Mbidde E, et al. ChlVPP combination chemotherapy for Hodgkin's disease: long term results. Brf Cancer 1990;62:279-85.

26 Hancock BW, Vaughan Hudson G, Vaughan Hudson B, Haybittle JL, Bennett MH, MacLennan KA, et al. British National Lymphoma Investigation randomised study of MOPP (mustine, Oncovin, procarbazine, prednisolone) against LOPP(Leukeran substituted for mustine) in advance Hodgkin's disease - long term results. Br f Cancer 1991;63:579-82.

27 Blayney DW, Longo DL, Young RC, Greene MH, Hubbard SM, Postal MG et al. Decreasing risk of leukemia with prolonged follow-up after chemotherapy and radiotherapy for Hodgkin's disease. N Engl f Med 1987;316: $710-4$.

28 International Agency for Research on Cancer. Some antineoplastic and immunosuppressive agents. Lyon: IARC, 1981. (IARC monographs on the evaluation of the carcinogenic risk of chemicals to humans, vol 26.)

29 Kaldor JM, Day NE, Band P, Choi NW, Clarke EA, Coleman MP, et ol Second malignancies following testicular cancer, ovarian cancer and Hodgkin's disease: an international collaborative study among cance registries. Int $\mathcal{f}$ Cancer 1987;39:571-85.

$30 \mathrm{Henry}$-Amar $M$. Quantitative risk of second cancer in patients in first complet remission from early stages of Hodgkin's disease. NCI Monogr 1988;6: 65-72.

31 Bennett MH, MacLennan KA, Vaughan Hudson G, Vaughan Hudson B. Non-Hodgkin's lymphoma arising in patients treated for Hodgkin's disease in the BNLI: a 20 year experience. Ann Oncol 1991;2(suppl 2):83-92.

32 Van Rijswijk REN, Sybesma JPHB, Kater L. A prospective study of changes in immune status following radiotherapy for Hodgkin's disease. Cancer 1984;53:62-9.

33 Kinlen LJ. Immunological factors. In: Schottenfeld D, Fraumeni JF Jr, eds. Cancer epidemiology and prevention. Philadelphia: Saunders, 1982:494-505.

34 International Agency for Research on Cancer. Some aromatic amines, hydrazine and related substances, $N$-nitroso compounds and miscellaneous alkylating agents. Lyons: IARC, 1974. (IARC monographs on the evaluation of the carcinogenic risk of chemicals to man, vol 4 .)

35 Tomatis $\mathrm{L}$ A Cancer: causes, occurrence and control. Lyons: International Agency for Research on Cancer, 1990. (IARC scientific publication No 100.)

(Accepted 10 January 1992)

\title{
Drowning and near drowning in children in the United Kingdom: lessons for prevention
}

\author{
Alison Kemp, J R Sibert
}

\section{Abstract}

Objectives - To determine the pattern of drowning and near drowning of children in Britain and identify means of prevention.

Design-Study of drowned and nearly drowned children under 15 years old.

Setting-United Kingdom, 1988 and 1989.

Subjects - Children under 15 years either drowning or admitted to hospital after a submersion incident.

Main outcome measures-Number of nearly drowned children, obtained from consultant paediatricians returning monthly notification cards through the British Paediatric Surveillance Unit. Number of drowned children notified by the Office of Population Censuses and Surveys and other national epidemiological offices; information from coroners.

Results - 306 children had confirmed submersion

Department of Child Health, University of Wales College of Medicine Community Unit, Lansdowne Hospital, Cardiff CF1 8UL Alison Kemp, senior registrar J R Sibert, professor of community child health

Correspondence to: Professor Sibert.

BMF 1992;304:1143-6 incidents: 149 died and 157 survived after near drowning. The annual incidence in England and Wales was $1 \cdot 5 / 100000$, and mortality $0 \cdot 7 / 100000$. Mortality was lowest in public pools 6\% (2/32) and highest in rivers, canals, and lakes $(78 \%, 56 / 73)$. Most of the children $(263,83 \%)$ were unsupervised at the time of the accident. $208(68 \%)$ children were under 5 years old.

Conclusions-Drowning and near drowning of children are problems in the British Isles. Appropriate supervision and safety barriers seem important for preventing such accidents. Improving infor- mation on dangers of drowning given to parents through the child surveillance programmes, encouraging fencing or draining of garden ponds and domestic swimming pools, and increasing supervision of swimming in lakes, rivers, and beaches should reduce the number of accidents.

\section{Introduction}

Drowning is the third commonest cause of accidental death in children in Britain after road traffic accidents and burns. ${ }^{1}$ Drowning has been responsible for an average of 72 childhood deaths annually for the past 10 years in the United Kingdom. ${ }^{2}$ The subject has been well researched in the water oriented societies of Australia, ${ }^{3}$ the United States ${ }^{45}$ and Canada ${ }^{6}$ but not in Britain. A study in Wales suggested that all United Kingdom data would be required before useful conclusions could be drawn. ${ }^{7}$ Not only is there high mortality after submersion incidents but some children sustain severe neurological deficit: we identified a 5.3\% incidence of such problems in children admitted to hospital. ${ }^{8}$

We present an integrated study of drowning and near drowning of children in the United Kingdom for the years 1988-9. We outline the extent of the problem, the details and sites of the accidents, and the children affected. We identify particular hazards and areas where preventive measures might be taken. 